Translated into French as "La croissance des entreprises rurales selon les regions et la propriete" and published in Revue d'Economie du Developpement, Juin 1999.

\title{
Some Observations on the Ownership and Regional Aspects in Financing the Growth of China's Rural Enterprises
}

\author{
Wing Thye Woo \\ Economics Department \\ University of California \\ Davis, CA 95616 \\ wtwoo@ucdavis.edu
}

May 6, 1999

\begin{abstract}
$\underline{\text { Abstract }}$
Rural enterprises (TVEs) have been the biggest contributor to China's growth in the last fifteen years but this may not continue. TVE investment has dropped from 8.5 percent of GDP in 1985-88 to 7.7 percent in 1992-97, while, over the same period, investment by state enterprises has stayed the about same, and total national investment went up by 4 percentage points of GDP. This outcome reflects discrimination against nonstate enterprises by the state-dominated capital markets, and the ambiguities that characterise the property rights of TVEs. Positive effects (spread effects) from the coastal boom on inland TVEs have been delayed because of incomplete economic deregulation, unequal regional policies, and natural geography.
\end{abstract}

Keywords: rural enterprises, financial intermediation, regional development, property rights, China, Asia

An earlier draft was presented at the International Conference on Chinese Economy: Openness and Disparities in China, Centre d'Etudes et de Recherches sur le Developpment International (CERDI), Universite d'Auvergne, Clermont-Ferrand, France, October 22-23, 1998. I am grateful to Sylvia Demurger, Fan Gang, Patrick Guillaumont, Aart Kraay, Chingboon Lee, Francoise Lemoine, Li Shantong, Pascal Mazodier, MaryFrancoise Renard, Wu Yanrui, and Zhai Fan for insightful and helpful comments. The results reported here are from the Economic Geography Project being undertaken at the Harvard Institute for International Development. 


\section{$\underline{\text { Introduction }}$}

The hallmark of Chinese economic growth since 1984 is that rural enterprises (popularly known as township and village enterprises, TVEs) have constituted the main engine of economic growth. ${ }^{1}$ The industrial output alone from rural enterprises accounted for about 31 percent of the increase in GDP between 1984 and 1993. ${ }^{2}$ It has been clear since the 15th Party Congress in September 1997 that China has decided to sharply reduce the importance of state-owned enterprises (SOEs) by accelerating the diversity of ownership forms. The amendment of the constitution in March 1999 to accord private ownership the same legal status as state ownership is a logical development from the 1997 policy decision. Implicitly, TVEs are expected to become an even more important engine of growth in the future.

This expectation of continued high TVE growth may be unrealistic however, given recent investment trends. TVE investment in the 1990s has declined relative to both GDP and total fixed investment, in a period in which total investment went from 30 percent of GDP in 1987 to 33 percent in $1997 .^{3}$

\begin{tabular}{|c|c|c|c|c|c|}
\hline \multirow{2}{*}{\multicolumn{2}{|c|}{$\begin{array}{l}\text { Fixed Investment } \\
\text { as \% of GDP }\end{array}$}} & \multirow{2}{*}{\multicolumn{2}{|c|}{$\frac{\text { Share of Fixed }}{\text { Investment, \% }}$}} & \multirow{2}{*}{\multicolumn{2}{|c|}{ Share of Industria }} \\
\hline & & & & & \\
\hline 1987 & $\underline{1997}$ & 1987 & 1997 & 1987 & 1997 \\
\hline 30.4 & 33.4 & 100.0 & 100.0 & 100.0 & 100.0 \\
\hline 19.2 & 17.5 & 63.1 & 52.5 & 59.7 & 25.5 \\
\hline 8.9 & 7.7 & 29.1 & 23.0 & 32.5 & 47.6 \\
\hline
\end{tabular}

So far, the TVEs have increased their output share not only without getting any of the investment share released by the shrinking SOE sector but doing so with a decreased investment share, from 29 percent in 1987 to 23 percent in 1997. This is unlikely to be a sustainable situation. It is hard to see how the TVEs could move up the value-added chain in production without significant capital investments in the near future. So, if China's

\footnotetext{
${ }^{1}$ As in many official Chinese statistical yearbooks, we will use the following terms interchangeably: rural enterprises, TVEs, and collectively-owned enterprises (COEs) and individually-owned enterprises (IOEs) located in the rural areas. TVEs started in the post-1978 era as owned collectively by the local rural communities, but the term now does not connote collective ownership. We will refer to collectively-owned TVEs as rural collectives.

${ }^{2}$ Obtained by modifying Woo's (1998) estimates with the assumption is that 85 percent of the ouput from COEs and IOEs are produced in the rural area, i.e. from TVEs. Output share in period varied according to data source e.g. exceeding 100 percent after 1990 when combining data from Township-Village Enterprise Yearbook and China Statistical Yearbook. The share of rural enterprises in investment by all COEs and IOEs was 80 percent in 1987 and 1997.

${ }^{3}$ Data from China Statistical Yearbook.
} 
market capitals continue not to allocate sufficient investment funds to the most dynamic sector of the economy, China's high growth rate is probably not going to continue in the medium run.

According to the standard core-periphery spatial model of economic development, an emerging core would grow by attracting resource inflows from the periphery (the backwash effects). Over time, as production costs, like congestion, land prices and wages, rise, capital and skilled manpower would move from the core to the neighboring provinces (the spread effects). Applying this model to China, the prediction would be that TVEs would first blossom in the coastal provinces because of easier integration into the international division of labor, and then later in the neighboring inland provinces. This implies that when TVE growth in the coastal provinces slows down, it is not necessary a cause for national concern. The problem in China after twenty years of rural deregulation is that the investment slowdown by the TVEs in the coastal provinces does not seem to have been accompanied by an increase in investment by TVEs in their neighboring provinces (the central provinces). ${ }^{4}$ Investment by both coastal TVEs and central TVEs are likely to have fallen as a share of GDP, as well as a share of total national investment!

$\frac{\text { Investment as }}{\text { of GDP, \% }}$
$\underline{1987 \quad 1997}$

Share of national investment, \% $\underline{1987 \quad 1997}$

$\begin{array}{lllllll}\text { TVEs in coastal provinces } & 4.0 & 3.5 & 13.1 & 10.4 & 35.6 & 35.7\end{array}$ $\begin{array}{lllllll}\text { TVEs in central provinces } & 2.6 & 2.0 & 8.7 & 6.0 & 23.5 & 20.7\end{array}$

Share of investments by all TVEs, $\%$ $\underline{1987 \quad 1997}$ provinces. The central TVEs' share of total TVE investment has in fact dropped from 24 percent in 1987 to 21 percent in 1997. The level of TVE investment and the existence of spread effects are important not only for economic reasons but also for political reasons. If the economic forces unleashed by the post-1978 reforms do not naturally generate sustained economic growth, and "trickling-down" to the rural areas and to the non-coastal provinces, then political forces could arise to push for the amelioration of rural-urban inequality and regional inequality. And there is no reason to believe that these political forces, without an understanding of the causes

\footnotetext{
${ }^{4}$ Definitions of coastal and middle provinces are given in the next section. TVE investment data across provinces are not available until 1993. For 1997, the share of coastal TVEs was 79.5 and the share of central TVEs was 79.4 percent almost identical to the national level shares in 1987 and 1997. The data below was calculated by assuming that TVE
} 
of the barriers to financing TVE investment, would not choose direct administrative controls to address these problems (which would worsen long-run economic performance), and create social instability at the same time.

Our paper has two aims. The first aim is to understand the decline in TVE investment by analysing the financing mechanisms for enterprises of different ownership forms, and in different provinces. The second aim is to use our knowledge of investment financing to suggest new policies to accelerate the growth of rural enterprises, especially in the non-coastal provinces.

\section{The Profile of TVEs Across Geographical Groupings}

Nineteen of China's thirty provinces ${ }^{5}$ can be quite naturally classified under four geographical groupings that are analytically distinct in economic terms:

- the five fast-growing coastal provinces of Fujian, Guangdong, Jiangsu, Shandong, and Zhejiang;

- the eight agricultural central provinces of Anhui, Henan, Hubei, Hunan, Jiangxi, Shaanxi, Shanxi, and Sichuan;

- the three industrial northeastern provinces of Heilongjiang, Jilin and Liaoning, and;

- the three prosperous cities with province-level status, Beijing, Shanghai, and Tianjin.

The remaining eleven provinces - Gansu, Guangxi, Guizhou, Hainan, Hebei, Inner Mongolia, Ningxia, Qinghai, Tibet, Xinjiang, and Yunnan - do not fit the criteria, in the broad sense, of being geographically similar or contiguous, having similar economic structure, and being at similar development level. We lump them under a fifth (residual) grouping called "other mainly non-coastal" because eight of them (that is excluding Guangxi, Hainan and Hebei) are inland provinces. These provinces vary widely in economic characteristics, e.g. landlocked Xinjiang has a per capita income higher than the national average, while landlocked Gansu and Guizhou are the two poorest provinces in China.

The key economic indicators of these five provincial groupings are shown in Table 1. The cityprovinces are major industrial, trade and administrative centers, with over 87 percent of their labor-force employed in secondary and tertiary industries. The average city-province has a per capita income that is 78

${ }^{5}$ In 1996, Chongqing became the fourth city to be given province level status. We have ignored this new province because 
percent above the average province in the second richest provincial grouping - the coastal provinces. The location of the biggest and most prosperous SOEs in these city-provinces provides linkages (supplier opportunities) for TVEs to develop around these cities. This linkage effect may be an important reason why the TVEs in city-provinces are significantly larger than in the other provincial groupings, 22 workers in an average city-province TVE versus 8 in an average coastal province TVE. The proportion of workforce employed by TVEs is naturally lower than the national average of 21 percent.

Under the pre-1984 central planning regime, the three northeastern provinces became the industrial heartland of China, and the core of the state enterprise sector. This is the part of China that bears the closest resemblance to the heavy industry bias of the classic Soviet economic structure. The strong legacy of traditional socialism has resulted in active legal discrimination against the establishment of non-state enterprises, and this has helped to render TVEs in the northeastern provinces to be the smallest in scale in China, 4 workers in a typical northeastern province TVE, despite the existence of linkage opportunities.

All the five coastal provinces have per capita income levels that are significantly above the national average. It is important to note that the above-average income of the coastal provinces is recent when compared with the city-provinces and the northeastern provinces. ${ }^{6}$ Prosperity came to the coastal provinces only after 1978 when the policies of economic reform and opening were implemented. A large part of the big income increases in the coastal provinces in the 1978-84 period was due to the agricultural boom. The post-1984 (even bigger) income increases were primarily the result of the industrialisation of the coastal provinces led by their dynamic TVEs. Almost 30 percent of their workforce are employed by TVEs.

All the eight central provinces have per capita incomes that are below the national average. Less than 20 percent of their labor force are employed in secondary industry compared to 47 percent for the cityprovinces, 33 percent for the northeastern provinces, and 29 percent for the coastal provinces. While the average number of TVEs in an central province is higher than in a coastal province, the average size of a central province TVE is smaller than that of a coastal province TVE - 5 persons and 8 persons respectively. Both the average size of TVEs and the proportion of labor force working in TVEs are at the national average.

we do not yet have the information that will allow us to separate the Chongqing data out from the Sichuan data.

${ }^{6}$ See Tian, Sachs and Warner (1996). 
It is clear that the experience of the coastal provinces is more relevant for the economic development of the central provinces than the experiences of the city-provinces and the northeastern provinces. The unusually high incomes of the city-provinces come from being industrial enclaves with no rural hinterlands, and the above-average incomes of the northeastern provinces were artificially created by the industrialisation dictated by the central plan. The northeastern provinces are now in fact in the throes of restructuring their Soviet-type economies to be compatible with the working of a market economy. The coastal provinces, in contrast, owe their above-average incomes to the fast development of rural enterprises after 1984. With the deepening of market reforms, it therefore seems natural to us to assume that path to prosperity for the central provinces is through the development of a dynamic rural enterprise sector. The question is what can be done to hasten the generation of spread effects from the booming coastal provinces.

\section{The Financial System in Rural China ${ }^{7}$}

The Agricultural Bank of China (ABC) was established in 1955 to provide financial services to the rural sector, and channel funds for the grain procurement purchases. Small-scale collectively-owned rural credit cooperatives (RCCs, Nongcun Xindai Hezuoshe) were started in the early 1950s, under the supervision of ABC, to be the primary financial institutions serving the rural areas. Although RCCs are independent accounting units owned by townships, or towns, or villages, or several villages jointly, they are, in practice, grassroot units of the Agricultural Bank of China (ABC). RCCs operate an extensive network of branches, savings deposit offices, and credit stations in market towns and remote areas. The number of RCC units rose from 389,726 in 1981 to 421,582 in 1984 , and then fell steadily to 365,492 in $1995 .{ }^{8}$ We want to highlight this decline in the number of RCC units after 1984 because this decline means a decrease in the effort to mobilise rural saving, and a decrease in the access of the rural community to investment financing.

Table 2 outlines the changes in the operations of RCCS in the reform era. It shows three turning points that coincide with other changes in China's economy. In 1978, RCCs lent only 27 percent of the deposits they

\footnotetext{
${ }^{7}$ For an excellent analysis of rural finance in China up to the mid-1980s, see Tam (1988).

${ }^{8}$ The number of RCC units is the number of RCCs plus the number of branches, saving deposit offices and credit stations. The number of RCCs (i.e. institutions with independent accounting systems) went up from 55,044 in 1981 to 60,897 in 1988, and then down to 50,219 in 1995. In 1995, RCCs accounted for 13 percent of deposits in all financial institutions, and 10 percent of all the loans made.
} 
collected in the rural area to finance rural economic activities. The first turning point was 1984 when the legal barriers against non-agricultural economic activities undertaken by farm households, and the establishment of rural enterprises were lowered, and the RCCs were allowed to make more loans in the rural areas. RCCs' loans to rural areas jumped from 34 percent of RCC deposits in 1983 to 57 percent in 1984. The proportion of RCC deposits going to rural loans increased every year in the 1984-1988 period, reaching 65 percent in 1988.1984 was also a turning for the SOE sector, it received its first significant dose of operational autonomy.

The second turning point was 1989 when the incremental dismantling of discrimination against rural lending was suspended. It marked the beginning of a period of tight credit, re-introduction of some administrative curbs on investment spending, and uncertainty as to future state policies on economic reform and trade opening. The loan-deposit ratio of RCCs stayed at about 66 percent in the 1989-91 period. The third turning point was 1992 when economic deregulation accelerated after Deng Xiaoping's inspection tour of southern China (nanxun) in early 1992, and enabled the loan-deposit ratio to continue increasing.

These three turning points produced distinctive economic responses. The suspension of reform in 1989 saw average annual investment (fixed capital formation) declined from 30 percent of GDP in 1984-88 to 25 percent in 1989-91, and the re-starting of economic deregulation saw the RCCs' loan-deposit ratio jumped to 71 percent in 1992 and investment to rise to 34 percent of GDP in 1992-97. We will use the three distinct periods identified here to organize the discussion in the subsequent sections.

It would be right to say that until the mid-1980s, the RCCs, by relending the bulk of their deposits to $\mathrm{ABC}$, serve primarily as tributaries by which rural savings were channeled to finance economic activities in the urban areas. RCCs still divert a significant proportion of their deposits to finance activities outside of the rural area, 27 percent of their deposits in 1995. The general fact is that non-SOEs face great difficulties in raising funds. The financial system is dominated by the state banks, and the state banks lent primarily to the SOEs. The access to bank loans by non-SOEs get particularly bad during periods of tight credit. In 1989, ceilings were imposed on loans to rural enterprises; and working capital credit from banks to private enterprises severely curtailed. (Banks gave virtually no fixed capital credit to private enterprises before then.) The result was that the number of private enterprises dropped from 225,000 in mid-1988 to 98,000 in early 1991. 
Private and small collective enterprises have always paid the higher interest rates in the informal credit markets. A 1992 field investigation reported that a fast-growing private electronic company ${ }^{9}$ paid an interest rate of 2.5 percent each month on its working capital; and its original start-up capital came from the savings of the partners and informal loans from friends. These informal credit markets, popularly referred to as "folk finance" (minjian rongzhi), appeared to have increased greatly in scope in recent years.

Given the heavy reliance by rural enterprises on non-formal investment financing, a new informal financial instrument called employee bond (jizi) has emerged as a significant source of funds. An employee bond is purchased by the new employee when she joins the enterprise, and it carries an interest rate at least equal to that of a time deposit with the same maturity. Many non-SOEs also issue a hybrid equity-bond instrument which, in addition to paying a fixed base rate, also pays a bonus rate -- the size of which is contingent on the profitability of the enterprise. In many cases, especially with rural collectives, tax exemption turned out to be an important source of investment financing. Since many counties, towns and villages are on tax-contracts with their upper levels that specify a fixed amount, they typically start exempting taxes once their tax quotas were reached provided that the extra retained funds would be invested. ${ }^{10}$

\section{Investment Performance of Rural Enterprises}

Table 3 summarises the financing of investment by enterprises of different ownership forms. ${ }^{11}$ Part A compares the absolute size of investment from each ownership type by expressing investment spending as a percent of GDP for each of the three analytical periods identified previously. Part B shows the relative size of investment by expressing investment spending of each ownership type as a percent of total investment.

While it is desirable that total investment has risen from 30 percent in 1985-88 to 34 percent in 1992-96 - a confirmation of the well-known international experience that economic deregulation increases economic efficiency and capital accumulation - it is extremely troubling that investment by rural enterprises (rural collectives and rural individuals) has actually shrunk over time, from 8.5 percent of GDP in 1985-88 to 7.7

9 Bao An county factory, September 28, 1992, Case A27 of author's fieldwork.

${ }^{10}$ In the author's 1992 fieldtrip, one Chongqing firm raised Y3 million from jizi to acquire its Y14 million of fixed assets, while a Chengdu firm raised Y1.5 million from jizi for the required fixed asset investment of Y8 million; case A39 and A34 respectively. One big Chengdu company was given tax concessions worth Y3.5 million a year to allow it to accumulate funds to double its present output; case A35. 
percent in 1992-96. SOE investment, on the other hand, rose slightly from 19 percent of GDP in 1985-88 to 20 percent of GDP in 1992-96. This anomalous situation is a bad sign for future economic growth, and for the reduction of rural poverty.

The biggest absolute increase in investment was from foreign-owned firms (including those owned by oversea Chinese). Their investment rose from negligible levels in 1985-92 to 4.1 percent of GDP in 1995. This big increase in investment in such a short time indicates the tremendous investment potential of foreign firms because of their access to international capital markets. Naturally, the obvious question is how to increase the access of TVEs in the central provinces to foreign capital.

Parts C and D track the financing of investments undertaken by enterprises of different ownership type. Part $\mathrm{C}$ focuses on where enterprises of each type of ownership get their investment funds by calculating the percent of investment that is funded by each financing source. Part D emphasizes the destination of the funds from each financing source by calculating the share of funds from each source received by enterprises of each ownership type. The definitions of the funding sources are as follows:

(a) State Budget: This source finances primarily projects specified in the state investment plan. The funds come from (1) direct budget appropriations, and (2) policy loans from state banks (that are, many times, backed by government deposits). The Chinese economic reforms have drastically reduced the scope of the state investment plan, and hence reduced "state budget" as a source of investment funding.

(b) Domestic Loans: Until the early 1990s, domestic loans were largely loans from the state banks that were backed by the banks' own funds and non-government deposits. Domestic loans also include investment loans from local governments, and from finance companies.

(c) Foreign Investment: Funds from (1) bonds and shares sold to foreigners (including Chinese from Taiwan, Hong Kong, and Macao) - who may hold the controlling shares - and (2) loans from international organisations that are managed or guaranteed by the government.

(d) Self-Raised Funds: These funds come mostly from (1) retained earnings, (2) bonds/shares sold to workers within the enterprises, and (3) the supervising agencies of the SOEs.

(e) Other Funds: This is more than a residual category. It also encompasses funds that are raised in the formal and informal bond and stock markets. In our usage, there are only two formal bond and equity markets in China because only those in Shenzhen and Shanghai have legal recognition. So we call all the other bond and equity markets (quite numerous but less developed in the poorer regions) "informal financial markets".

Parts C and D suggest five immediate policy issues for promoting the growth of the more dynamic TVE sector. The first policy issue is that even though the SOE share of domestic loans has declined, SOEs continue

\footnotetext{
${ }^{11}$ Data are from various issues of the China Statistical Yearbook, and are available only from 1985 onward.
} 
to have disproportionate access to domestic loans and hence are retarding the growth of TVEs. The reasoning follows from that:

(loans to SOEs/output of SOEs) $=$ (loans to SOEs/GDP) / (output of SOEs/GDP)

The (loans to SOEs/output of SOEs) ratio has increased very significantly in the 1985-96 period because (a) the annual average (loans to SOEs/GDP) ratio has gone up from 4.1 percent in the 1985-91 period to 5.1 percent in the 1992-96 period, and (b) the (output of SOEs/GDP) ratio has gone down greatly as evidenced by the drop in the SOE share of total industrial output from 65 percent in 1985 to 28 percent in 1996.

The second policy issue is that despite the drop in SOE share of total domestic loans, the rural sector's share did not go up. The rural sector's share averaged 18 percent in both the 1985-88 and 1992-95 periods. The loan share "released" by the SOEs went entirely to help finance the investments of the foreign-owned firms. The absolute amount of resources transferred by domestic loans to rural enterprises showed little change over time, 1.1 percent of GDP in 1985-88 and 1.3 percent in 1992-95, a paltry increase of 0.2 percentage point.

The third policy issue is that while rural enterprises have recently gained access to "foreign investment," their share of this fund is disproportionately small. TVEs received only 8.2 percent of the total foreign capital inflow into China in the 1992-96 period; and foreign funds financed only 3.4 percent of TVE investment in this period. In the same period, the SOEs absorbed 49.6 percent of the foreign investment.

The fourth policy issue is that the access of the rural enterprises to funds from the fast growing "other funds" has declined precipitously recently. "Other funds" which we take to be a proxy for informal credit has grown from 2.9 percent of GDP in 1985-88 to 4.7 percent in 1992-96, but the TVEs' share of it has fallen from 31 percent in 1985-88 to 27 percent in 1992-96, with the share being 6.1 percent in 1995 and 11.4 percent in 1996.

The fifth policy issue from Parts C and D is that in light of the limited access that TVEs have to foreign funds and domestic loans, it is troublesome that the chief source for financing TVE investments - self-raised funds - has declined in size over time, from 6.4 percent of GDP in 1985-88 to 4.8 percent of GDP in 1992-96. The drop in self-raised funds deserves serious study to determine whether it is the result of increased competition from the entry of new TVEs or the result of increased compensation to managers and workers. If the drop in retained earning is due to over-compensation of personnel in rural collectives, then the corporate 
governance structure and ownership form of rural collectives has become a barrier to the dynamic growth of the TVE sector.

\section{$\underline{\text { Regional Contrast in the Financing of Investments by Rural Collectives }}$}

The only dataset that is consistent over time on the sources of investment financing for rural enterprises in different provinces is from the Township-Village Enterprises Yearbook (TVEY) published by the Ministry of Agriculture, and we face several difficulties in using it. ${ }^{12}$ The first difficulty is that the TVEY dataset covers only the component of the TVE sector that is registered as collectively-owned, i.e. only rural COEs.

The second difficulty is that the classification scheme for the sources of funds in TVEY is also different from the classification scheme in the China Statistical Yearbook (CSY), displayed in Table 3, with the former being more detailed. From our analysis of the data and from our conversations with the statistical authorities, it appears that the approximate correspondence between the two classification schemes is as follows:

$\begin{array}{lll}\text { China Statistical Yearbook } & & \text { Township-Village Enterprise Yearbook } \\ \text { State Budget } & = & \text { State Budget } \\ \text { Domestic Loans } & = & \text { Bank and Credit Union Loans } \\ \text { Foreign Investment } & = & \text { Foreign Funds } \\ \text { Self-Raised Funds } & \quad \text { Funds from Supervising Agency }+ \text { Bonds Sold to Employees } \\ & \quad+\quad \text { Other Internal Funds } \\ \text { Other Funds } & = & \text { Other Sources + Other Funds Raised Outside of the Firm }\end{array}$

The third difficulty we face in using the investment data in TVEY is that, in some years, their values differ significantly problem with those in e investment data from the CSY. The CSY, as noted earlier, does not separate provincial COEs into rural and urban categories until from 1993 onward. If the data in both sources are correct, then the data on investments by rural COEs in TVEY should always be smaller than the data investment by all (rural and urban) COEs in CSY. Such is not the case however. The TVEY data on investment by rural COEs data is smaller than the CSY data on investment by all COEs in the 1987-91 period, but larger in the 1992-96 period. The former is 66 percent of the latter in 1987, and 112 percent in 1996.

The larger investment figures in TVEY in the first-half of the 1990s could be due to exaggerations by local officials to make themselves look good. The exaggeration of TVE output is a well-documented phenomenon. For example, the 1996 CSY revised significantly downward the 1991-1994 gross industrial 
output from COEs and IOEs reported in the 1995 CSY, which were compatible with figures in TVEY. After the data revision, CSY reported 1993-95 gross industrial output from COEs and IOEs that were smaller than in TVEY. So it is likely that the TVEY investment data are also exaggerated. The implication is that we should not draw any conclusions based on the levels of investment reported in TVEY (e.g. investment as percent of GDP). To the extent that the degree of exaggeration in values are roughly uniform across provinces, and across funding sources, then some ratios of these numbers could provide some useful information. ${ }^{13}$

With this point in mind, Table 4 is constructed to contrast the financing of investments by rural collectives in the coastal provinces and in the middle provinces in the 1987-95 period in two ways (a) the group's share of funds from each source, i.e. the group's share of the national total of each type of fund, and (b) the proportion of each group's total investment that is funded by each of the funding sources. Since the use of the group average can mis-state the situation of a particular member of the group, we have also included the data for Shandong and Sichuan. Shandong is the most populated coastal province, and Sichuan is the most populated middle province. ${ }^{14}$ Since Shandong is the poorest of the coastal provinces, and Sichuan has a per capita income that is lower than the average per capita income of the central provinces, our discussion will be more sensitive to the financing situation in the poorer provinces within each provincial grouping.

The detailed data (available from author) show a highly unequal distribution of investment funds. Up to 1994, rural collectives in the five coastal provinces raised more funds from each financing source than rural enterprises in the eight central provinces. During the 1987-96 period, the coastal provinces attracted 47 to 60 percent of the national total of investment funds going to rural collectives while the central rural collectives attracted 16 to 28 percent. The disparity is even greater when we compare the poorer provinces within each provincial grouping. In 1996, rural collectives in Shandong accounted for 17 percent of the investment by all rural collectives, while rural collectives in Sichuan accounted for just 4 percent.

\footnotetext{
12 The 1989 TVEY does not contain the investment financing information for 1998, so there's a gap in the dataset.

${ }^{13}$ The difference in magnitude between the TVEY data and the CSY data could also be due to many other reasons, e.g. possible differences in definition, changes in definitions over time in one source but not the other. We do know that the two sources generated their estimates from different samples - the TVEY relied on annual reports submitted to the TVE Bureau in the Ministry of Agriculture, and the CSY relied on a survey conducted by the Rural Socio-Economic Survey Organisation in the State Statistical Bureau.

${ }^{14}$ Sichuan is also the most populated province in China.
} 
The data also show that state-directed investment funds did not seek to ameliorate this disproportional flow of funds to the coastal rural collectives. Until 1995, the state budget had always invested much more in the coastal rural collectives (over 40 percent) than in the central rural collectives (under 30 percent). The disbursement of investment funds by the supervising agencies is even more skewed than the state budget allocations, and the volume of funds from the supervising agencies is two to three and half times higher than that from the state budget.

In our judgement, the unequal outcome is largely due to incomplete economic reforms, unequal regional policies, and natural geography, which together rendered the rate of return to capital higher in the coastal provinces than in the central provinces. The gradual dismantling of the central credit allocation plan started in the second half of the 1980s, and the permitted degree of financial market liberalization differed across provinces. The official toleration of informal financial markets occurred earliest, and is greatest, in the coastal provinces, and hence the informal financial markets in the coastal provinces have become the most developed in China. Because the interest rate in the liberalised financial markets are higher than the regulated interest rates of the state banking system, funds have flowed to the coastal provinces from the provinces which lag in financial deregulation and financial development.

The central government has extended special development incentives to many regions in the coastal provinces. These coastal regions are exempted from many economic regulations (e.g. those governing foreign investments), and from several type of taxes (e.g. import duties). The central government also allocates more funds (via the budget and state banks) for infrastructure investment in the coastal provinces. In short, throughout the 1980s and the beginning of the 1990s, central government actions raised the rate-of-return on capital in the coastal provinces relative to the rate-of-return on capital in the central provinces by deregulating and favoring the coastal provinces more than the central provinces.

Finally, natural geography has also contributed to the higher rate of return to capital in the coastal provinces. The inadequate transportation network in China naturally meant that the economic opening of China inevitably allowed the coastal provinces not only to be the first to be integrated into the international division of labor, but also to be the only provinces (for a considerable period of time) to be integrated into the international economy. 


\section{A Spread Effect in the Making?}

The comparison at the beginning of this paper of 1987 and 1997 data from CSY on the regional investment pattern of TVEs suggested that the coastal provinces were not yet generating a spread effect to benefit the central provinces. This suggestion was based on two observations. First, the coastal provinces' share of investment by all TVEs was 36 percent in both 1987 and 1997, while the central provinces' share had dropped from 24 percent to 21 percent. Second, the decline in the investment of coastal TVEs from 4.0 percent of GDP in 1987 to 3.5 percent in 1997 was mirrored in the investment of central TVEs which went from 2.6 percent to 2.0 percent. These two observations still held when we restricted the sample to rural collectives.

We must emphasize that the TVEY data do not contradict the above two observations even though:

- Part A of Table 4 shows that the central rural collectives' share of investment by all of China's rural collectives rose from 18 percent in 1989-91 to 23 percent in 1992-96 (with the coastal rural collectives' share was about 53 percent throughout 1989-96); and

- the investment of rural collectives in the central provinces (in calculations not shown here) rose from 0.6 percent of GDP in 1987 to 1.3 percent in $1996 .^{15}$

There is no contradiction because, first, the periods of comparison do not correspond due to data limitations. The CSY data allow us to compare investment between two periods with roughly the same policy regime (1985-88 and 1992-96), while the TVEY data requires us to compare investment across two different policy regimes (the dirigiste period 1989-91 versus the more liberal period of 1992-96). Second, we know that investment values in TVEY (even when transformed to be a proportion of GDP) are exaggerated.

We think that while it is likely that there has not been a spread effect from the coastal TVEs, Table 4 appears to show that one may be in the making. Table 4 indicates that proportionally more investment funds are following to the rural collectives in the central provinces. Compared to the austerity period of 1989-91, the TVEs in the central provinces have increased their shares of funds from all eight financing sources in the postnanxun period of 1992-96. Coastal rural collectives generally received smaller shares of funds from domestic

\footnotetext{
${ }^{15}$ As is the case in aggregate data, the 1996 investment of the rural and urban COES in the central provinces in CSY is lower than in TVEY; 0.8 percent of GDP versus 1.3 percent.
} 
funding sources in the post-nanxun period. If not for the large increase in the volume of foreign capital inflow in the 1992-96 period that the coastal provinces absorb a disproportionate amount of, their share of total investment by rural collectives would not have been maintained.

The most dramatic increases in shares of funds received by central rural collectives occurred where the financing sources are most market-oriented: "foreign funds" and "other funds raised outside of the firms". ${ }^{16}$ A significant part of the increased foreign capital inflow since 1992 has gone to the central rural collectives, lifting their share of foreign funds from 4 percent in 1989-91 to 11 percent in 1992-96. For "other funds raised outside of the firm," the central rural collectives have increased their share of this category of funds from 21 percent to 32 percent over these periods. In fact, by the end of 1996, the central rural collectives share of "other funds raised outside of the firm" was twice the share of the coastal rural collectives, 45 percent and 22 percent respectively.

There are many reasons for why the domestic funds that are market-driven funds have flowed in greater proportions to the central provinces in the post-nanxun period. The three important reasons in our opinion are (a) significant economic deregulation, (b) de facto clarification of the property rights of the rural collectives, and (c) the decrease in underemployment of the labor force of the coastal provinces.

The first important reason is that in the post-nanxun period, there has been more economic deregulation in the central provinces than in the coastal provinces. This is because the coastal provinces have already undertaken the same deregulation steps in the 1980 s - and so the additional deregulation steps implemented in the coastal provinces after 1992 were not equivalent in scope to those implemented earlier in the coastal provinces, and to those implemented in the central provinces after 1992. In brief, there has been a diminution of the central-coastal gap in economic regulation. ${ }^{17}$

Economic deregulation in the central provinces mainly meant the creation of a more business-friendly economic environment. The most basic of such deregulation involved the reduction of legal barriers to the formation of new businesses; the reduction of the supervisory role of local officials in production, investment,

\footnotetext{
${ }^{16}$ For the central rural collectives, "other funds raised outside of the firms" mainly refer to revenue obtained by central rural collectives from selling stocks and bonds in informal financial markets.

${ }^{17}$ The central provinces have become more deregulated than before, but their level of deregulation is still lower than of the coastal provinces.
} 
and hiring/firing decisions of firms; and the reduction of taxes and levies (formal and informal). The point here is that economic deregulation in the central provinces has raised the productivity of capital, and this has attracted more capital flows from abroad and elsewhere in China. ${ }^{18}$

The second important reason for the reallocation of domestic of domestic funds is that many central provinces have followed the lead of the coastal provinces in allowing their rural collectives to change to ownership forms that have clearly defined and legally protected property rights that are (potentially, if not already) freely tradable. The most common practice is to transform rural collectives into shareholding cooperatives. ${ }^{19}$ With the movement to clear, legal, and tradable property rights for rural collectives in the central provinces, outside investors have become more confident that their investments are now better secured against embezzlement. Outsider investors have hence sent a larger share of their funds to invest in the now more deregulated (i.e. more profitable) economies of the central provinces.

The third important reason for the new tendency of market-driven funds to flow to the central provinces is that labor cost in the coastal provinces have risen significantly. The fast growth of rural enterprises in the coastal provinces in the 1980s have now largely eliminated the underemployment in their rural labor force, and this caused their rural wages to rise. The result is two opposite flows between the coastal provinces and the central provinces. Labor has been flowing from the central provinces to the coastal provinces in response to the higher wages in the coastal provinces, and capital is now beginning to flow from the coastal provinces to the central provinces in response to the lower wages in the central provinces. It must be emphasized however that until China's transportation system is significantly improved to give the central provinces much easier access to the ports, this type of capital inflow into the central provinces will be temporary.

${ }^{18}$ In a 1997 fieldtrip, the author found many examples of post-1992 deregulation, e.g.

- a village in Henan which reduced the approval time for new businesses from six months to a month. Furthermore, the Party secretary posted signs on new businesses forbidding local officials who are not members of the village tax bureau from collecting any fines or fees.

- a county in Sichuan which established a "private enterprise development zone" under the direct control of local Party leaders to ensure that the discriminatory regulations against non-state enterprises would no longer be applied.

${ }^{19}$ In most cases, the registration status of the enterprise remains as "collective-owned" despite the transfer of most of the shares of the enterprise to the workers because of the existence of (minority) shares that are designated as collective-owned and are non-tradeable. 
Improving the Financing of Rural Enterprises

As pointed out earlier, the general prospects for future TVE growth is actually not very promising. TVE investment dropped by 1.8 percentage points of GDP during the 1985-96 period, even though total domestic investment increased by over 4 percentage points of GDP; and the TVE share of total domestic investment has dropped from 28 percent in 1985-88 to 22 percent in 1992-96. In our opinion, the primary reason for this drop in TVE investment (as a share of GDP and as a share of total domestic investments) is that TVEs suffer from two big disadvantages in investment financing.

The first disadvantage suffered by TVEs is that the still heavily-regulated financial system is directing too much of the investment funds to the SOE sector, thus starving the TVEs sector of investment funds. SOE investment has actually risen slightly as a share of GDP in 1992-96 despite the facts that the share SOE output in GDP has fallen, and that the SOE sector is less profitable and less efficient than the TVE sector.

The second major disadvantage of the TVEs in raising capital is that TVEs generally do not have forms of property rights that attract market-driven investment funds. We see this clearly in the failure of the TVE sector to significantly increase their shares of funds from the banking sector, foreign capital flows, and funds raised in the formal and informal financial markets. As the banking sector began to commercialise its lending activities in the 1990s, a smaller proportion of bank loans flowed to the SOE sector, but the "released share" went entirely to firms of other ownership structure e.g. shareholding companies and foreign-owned companies.

The three most important issues that must be addressed in order to overcome the above two crippling disadvantages faced by TVEs in getting investment financing are: the financial system is over-regulated, the RCC-ABC system lacks the organisational flexibility and incentive to focus on efficient local financial intermediation, and some ownership forms of TVEs discourage outside investment into TVEs.

\section{Deregulating the Financial Sector}

This is a much discussed issue in the Chinese press $^{20}$, but unfortunately many of the financial reform proposals are actually proposals for administrative reorganisation of the existing financial institutions rather

\footnotetext{
${ }^{20}$ For example, two recent articles in the China Daily are "Financial system to undergo five major changes," (February 28 , 1998); and "Reforms to target SOEs and State banks," (February 17, 1998).
} 
proposals for using market forces to allocate funds. Marketisation of the financial system involves at the minimum (1) allowing the establishment of privately-owned financial institutions; (2) freeing deposit and loan rates; (3) permitting foreign financial institutions to increase the scale and range of their operations over time; (4) imposing identical supervisory oversight and prudential standards on state-owned, and private-owned banks; and (5) instructing the state banks to stop giving preferential credit to SOEs, and to process loan applications equally without regard to ownership forms of the enterprises. ${ }^{21}$

The above financial reforms will stop the disproportionate flow of credit to the SOE sector, and free up the funds for the more productive projects in the non-state sector; and allow the appearance of new small-scale local financial institutions that will mobilise local savings to finance local TVE investments. Since the adoption of the policies of economic reform and opening in 1978, folk finance (minjian rongzhi) has grown impressively despite the absence of legal recognition and legal protection. Folk finance was definitely the source of the development of TVEs in Wenzhou city in Zhejiang Province. Liu (1992) reported that:

"Ninety-five per cent of the total capital needed by the local private sector has been supplied by "underground" private financial organizations, such as money clubs, specialized financial households and money shops ..."22

It is important to keep in mind that financial deregulation has to be accompanied by the introduction of adequate banking supervision and of prudential standards that comply with international norms. The rash of banking crises in Eastern Europe in the early 1990s and in East and Southeast Asia recently should serve as warnings of financial deregulation without adequate improvement in the government's ability to monitor the activities of the financial institutions.

$\underline{\text { Reorganising the RCC-ABC system }}$

\footnotetext{
${ }^{21}$ The Export and Import Bank of China has recently decided "to gradually expand its financial services to collectivelyowned firms and joint-stock companies" and to continue making "the large- and medium-sized State-owned firms .. as its major clients" (China Daily, "Bank loans to non-State enterprise," January 22, 1998). This decision is a step in the right direction, but it is a very inadequate one because of the continued discrimination against private enterprises - which makes a mockery of the heading of the article.

${ }^{22}$ The power of market forces (when tolerated by the local authorities) to induce financial institutional innovations is an old story. Taiwan's small and medium private enterprises exhibited dynamic growth in the 1960-1985 period even though they were heavily discriminated against by the (wholly state-owned) banking system because informal financial markets (curb markets) appeared to cater to their needs, Shea and Yang (1994).
} 
There is now a wealth of international experiences with various schemes in developing countries to direct investment credit to the rural areas where the bulk of the population, as well as where the bulk of the poor, live. In particular, we wish to draw attention to the successful Indonesian experience of establishing a selfsustaining and profitable banking system (the Unit Desa system) in the countryside to provide a starting point for the discussing how to accelerate financial development in rural China. Indonesia is very similar to China in key economic and institutional features. Like China, Indonesia is a geographically vast, and heavily populated economy, and its rural financial system is dominated by branches of a state bank (Bank Rakyat Indonesia, BRI) which has been designated to serve the rural areas. ${ }^{23}$

The Indonesian experience with the Unit Desa system suggests that the reorganisation of the RCC-ABC system be guided by five principles. The first key guiding principle is that a large-scale subsidised credit program for the rural areas cannot be sustained because it is both too expensive and too inefficient. A developing country like China should avoid wasting its scarce capital by using the interest rate mechanism to allocate funds to the projects with the highest rates of return.

The second key principle is that the role of government subsidies is to provide seed money to (1) provide technical training, (2) start the credit unit's lending activities, and (3) cover the losses for the first few years. Over time, the rural credit unit must (1) mobilise local savings to expand its lending activities, (2) improve its loan assessment activities in order to increase profits, and (3) build a reserve fund to cover losses.

The third key principle is that the rural credit unit must be given the incentive to maximise profits in a prudent manner. This third principle necessitates that each credit unit be given a large degree of operational autonomy in return for being financially accountable to the supervising branch of $\mathrm{ABC}$. Bailouts should be used only in exceptional cases where losses are clearly not due to incompetence or recklessness, and bonuses and promotion should be clearly based on contribution to the bank's profitability. Only in an environment with clearly defined individualised rewards and general hard budget constraint, would a credit unit apply itself to mobilise savings diligently, and to assess loan applications carefully.

The fourth key principle is that rural loan rates are generally higher than in the urban areas. This

${ }^{23}$ See Patten and Rosengard (1990), Woo (1995), and Yaron, McDonald and Piprek (1997) for details of the Indonesian case. 
situation does not generally indicate exploitation, it reflects instead the higher costs of making many small loans, and the absence of collateral to cover losses.

The fifth principle is that no rural bank should be given privileges that allow it to monopolise the local market. This is because providing credit to the rural poor is a hard job. The rural poor are many times unaware of their eligibility for loans, and can be physically hard to reach. Only a bank that is facing competition will attempt to reach these groups with advertisement campaigns, and with mobile teams. Without competition, a bank may even actually reduce its presence in the rural areas like the 13 percent reduction in the number of RCC units in the 1984-95 period - echoing the textbook monopolist who maximises profit by restricting supply.

The following four steps should be simultaneously implemented in order to strengthen the working of the reorganised RCC-ABC system:

1. The existing rural cooperative funds (nongcun hezuo jijin), rural credit cooperative (nongcun xindai hezuoshe), and other folk finance institutions (minjian rongzhi) should be given legal status as independent financial institutions. This will ensure that the RCC-ABC system will no longer enjoy its present nearmonopoly status.

2. Various departments of rural development within the different ministries may establish and operate rural financial institutions, but none of them should have regulatory power over institutions that they do not own.

3. The supervision of these independent rural financial institutions should be the sole responsibility of the People's Bank of China in order to ensure consistent regulation of all financial institutions, and to avoid over-regulation of the rural financial institutions.

4. The People's Bank of China should adjust the different mandatory asset-liability ratios to recognise that rural financial institutions face higher transaction costs (due to numerous small loans) and higher risk premia (due to absence of collateral), and that they serve the poorest portion of the population.

It is of fundamental importance to emphasize the point that the proposed $\mathrm{ABC}$ credit unit system could

work satisfactorily only with competition from other rural financial institutions. Wenzhou's experience with investment financing in the 1980s leaves no doubt about the beneficial effects of vigorous competition from folk finance on state-owned financial institutions:

"In order to compete with [the new folk finance institutions]..., as early as 1980 a local collective credit union, without informing the superior authority, abandoned for the first time the fixed interest rate and adopted a floating interest rate which fluctuated in accordance with market demand but remained within the upper limit set by the state. Despite the dubious legality of the floating interest rate, the local state bank branches and all the credit unions in Wenzhou had already adopted it before the central state officially ratified it in 1984." Liu (1992).

Allowing Rural Enterprises to Assume Market-Determined Ownership Forms 
The fact is that profit-maximising investors do not feel that their interests would be protected in TVEs where their property rights are less clearly defined, less protected legally, and not freely tradable like the property rights of shareholding firms and foreign-owned companies. The present trend of restructuring TVEs into shareholding cooperatives by dividing their assets among the workers (sometimes, among the original inhabitants of the community) is hence an important step in addressing the difficulties faced by TVEs in raising investment funds.

The transformation of TVE into shareholding cooperatives is akin to the present process of transforming most SOEs into shareholding companies. The transformation of TVES and SOEs into shareholding companies is a natural convergence to an enterprise form which, international experiences have shown, assures investors that managers would have the incentives to maximise profits in a prudent manner. If the property rights of TVEs fail to become freely tradable in formal stock markets, their share of total investment funds will be reduced further because the former SOEs (now transformed into normal corporations) will be the more attractive investment vehicle. The failure to turn TVEs into normal corporations will almost certainly mean that foreign institutional investors, who represent the biggest pool of investment fund in the world and who also have less inside information about the operations of TVEs than Chinese investors, will not become significant investors in TVEs.

\section{Final Remarks}

We attribute the slowdown in TVE investment in the 1990s to continued discrimination against nonstate enterprises by the capital markets (which are dominated by state financial institutions), and to ambiguities in the property rights of TVEs. And, we think that the best ways to increase the amount of investment in the non-coastal provinces are to (1) implement the proposed economic deregulation in the non-coastal provinces at a pace that should at least equal to that of the coastal provinces; and (2) improve the transportation links to the coastal provinces to end the tyranny of geography that has prevented the effective integration of the non-coastal provinces into the international economy. 


\section{References}

Jian, Tianlun, Jeffrey Sachs, and Andrew Warner, "Trends in Regional Inequality in China," China Economic Review, Vol. 7, No. 1, 1996.

Liu, Yia-Ling, "Reform From Below: The Private Economy and Local Politics in the Rural Industrialization of Wenzhou," China Quarterly, No. 130, June 1992, pp.293-316.

Patten, Richard and Jay Rosengard, "Progress with Profits: The Development of Rural Banking in Indonesia," Harvard Institute for International Development Working Paper, 1990.

Shea, Jia Dong and Ya-Hwei Yang,"Taiwan's Financial System and the Allocation of Investment Funds," in Joel Aberbach, David Dollar and Kenneth Sokoloff (ed.), The Role of State in Taiwan's Development, M.E. Sharpe, Armonk, N.Y., 1994, pp. 193-230.

Tam, Kit-On, “Rural Finance in China,” China Quarterly, March 1988, pp. 61-76.

Woo, Wing Thye, “Indonesia," in Financial Systems and Economic Policy in Developing Countries, edited by Stephan Haggard and Chung H. Lee, Cornell University Press, 1995, pp.76-112.

Wing Thye Woo, “Zhongguo Quan Yaosu Shengchan Lu: Laizi Nongye Bumen Laodongli Zai Pei Zhi de Shouyao Zuoyong (Total Factor Productivity Growth in China: The Primacy of Reallocation of Labor from Agriculture )" in Jingji Yanjiu, Vol. 3, 1998b, pp. 31-39.

Yaron, Jacob, Benjamin McDonald, and Gerda Piprek, "Rural Finance: Issues, Design, and Best Practices," Environmentally and Socially Sustainable Development Studies and Monograph Series No. 14, World Bank, 1997. 
Table 1: Economic Indicators Across Provinces in 1995

\begin{tabular}{|c|c|c|c|c|c|c|c|c|c|}
\hline \multirow[t]{2}{*}{ regions } & \multirow[t]{2}{*}{ (a)population } & \multirow{2}{*}{$\begin{array}{r}\text { (b) GDP per } \\
\text { capita }\end{array}$} & \multirow{2}{*}{$\begin{array}{l}\text { (c) Total number } \\
\text { of employees }\end{array}$} & \multirow{2}{*}{$\begin{array}{r}\text { (d) Percent of } \\
\text { employees in TVEs }\end{array}$} & \multirow{2}{*}{$\begin{array}{r}\text { (e) Number of } \\
\text { TVEs }\end{array}$} & \multirow{2}{*}{$\begin{array}{r}\text { (f) Number of } \\
\text { workers per TVE }\end{array}$} & \multicolumn{3}{|c|}{ (a) Distribution of Labor Force, \% } \\
\hline & & & & & & & primary & |secondary & tertiary \\
\hline unit & 10,000 & yuan/person & 10,000 & & $\begin{array}{r}10,000 \\
\end{array}$ & & industry & industry & industry \\
\hline & & & & & & & & & \\
\hline Total & $123,669.5$ & $4,631.5$ & $62,388.0$ & $20.6 \%$ & $2,202.7$ & 5.8 & 52.9 & 23.0 & 24.1 \\
\hline \multicolumn{10}{|c|}{ Coastal Provinces } \\
\hline Fujian & $3,328.9$ & $6,490.2$ & $1,567.0$ & $30.1 \%$ & 66.7 & 7.1 & 50.4 & 23.7 & 25.9 \\
\hline Guangdong & $7,051.6$ & $7,631.9$ & $3,656.8$ & $29.3 \%$ & 144.7 & 7.4 & 37.5 & 28.6 & 33.9 \\
\hline Jiangsu & $7,273.3$ & $7,087.9$ & $3,765.4$ & $24.6 \%$ & 92.4 & 10.0 & 41.7 & 33.8 & 24.5 \\
\hline Shandong & $8,962.5$ & $5,581.4$ & $4,625.4$ & $31.1 \%$ & 175.2 & 8.2 & 54.4 & 25.1 & 20.5 \\
\hline Zhejiang & $4,446.7$ & $7,926.8$ & $2,700.7$ & $29.5 \%$ & 90.2 & 8.8 & 42.7 & 31.4 & 25.9 \\
\hline Average & $6,212.6$ & $6,832.8$ & $3,263.1$ & $28.9 \%$ & 113.8 & 8.3 & 45.3 & 28.5 & 26.1 \\
\hline \multicolumn{10}{|c|}{ Middle provinces } \\
\hline Anhui & $6,184.4$ & 3,239.7 & $3,206.8$ & $18.6 \%$ & 60.7 & 9.8 & 60.7 & 17.9 & 21.4 \\
\hline Henan & $9,354.4$ & $3,210.0$ & $4,696.7$ & $15.2 \%$ & 89.5 & 8.0 & 60.0 & 19.8 & 20.2 \\
\hline Hubei & $5,935.8$ & $4,028.8$ & $2,707.0$ & $24.5 \%$ & 146.8 & 4.5 & 51.1 & 22.0 & 26.9 \\
\hline Hunan & $6,586.5$ & $3,333.6$ & $3,506.1$ & $20.6 \%$ & 185.0 & 3.9 & 61.4 & 16.3 & 22.3 \\
\hline Jiangxi & $4,173.4$ & $2,887.6$ & $2,059.2$ & $21.4 \%$ & 106.2 & 4.1 & 55.4 & 18.1 & 26.5 \\
\hline Shaanxi & $3,609.3$ & $2,770.7$ & $1,774.4$ & $18.5 \%$ & 72.2 & 4.6 & 59.5 & 19.2 & 21.3 \\
\hline Shanxi & $3,164.9$ & $3,451.9$ & $1,460.4$ & $27.9 \%$ & 70.9 & 5.7 & 43.5 & 29.8 & 26.7 \\
\hline Sichuan & $11,633.4$ & $3,037.8$ & $6,335.3$ & $18.2 \%$ & 252.4 & 4.6 & 63.1 & 15.9 & 21.0 \\
\hline Average & $6,330.3$ & $3,243.4$ & $3,218.2$ & $20.6 \%$ & 123.0 & 5.1 & 56.8 & 19.9 & 23.3 \\
\hline \multicolumn{10}{|c|}{ Northeast provinces } \\
\hline Heilongjiang & $3,809.4$ & 5,288.3 & $1,552.4$ & $13.5 \%$ & 62.5 & 3.4 & 36.8 & 34.1 & 29.1 \\
\hline Jilin & $2,668.9$ & $4,231.0$ & $1,254.5$ & $17.0 \%$ & 65.8 & 3.2 & 44.8 & 26.7 & 28.5 \\
\hline Liaoning & $4,213.6$ & $6,629.4$ & $2,034.0$ & $21.3 \%$ & 74.0 & 5.9 & 31.1 & 37.9 & 31.0 \\
\hline Average & $3,564.0$ & $5,552.9$ & $1,613.6$ & $17.3 \%$ & 67.4 & 4.2 & 37.6 & 32.9 & 29.5 \\
\hline \multicolumn{10}{|c|}{ Cities with province status } \\
\hline Beijing & $1,290.1$ & $10,812.3$ & 669.5 & $14.7 \%$ & 6.3 & 15.7 & 10.6 & 40.1 & 49.3 \\
\hline Shanghai & $1,458.1$ & $16,888.9$ & 768.0 & $18.2 \%$ & 1.6 & 87.4 & 9.2 & 51.4 & 39.4 \\
\hline Tianjin & 970.4 & $9,481.8$ & 489.7 & $21.4 \%$ & 7.6 & 13.8 & 16.9 & 48.4 & 34.7 \\
\hline Average & $1,239.5$ & $12,847.8$ & 642.4 & $18.1 \%$ & 5.2 & 22.1 & 12.2 & 46.6 & 41.1 \\
\hline
\end{tabular}

\begin{tabular}{|c|c|c|c|c|c|c|c|c|c|}
\hline \multicolumn{10}{|c|}{ Other mainly non-coastal provinces } \\
\hline Gansu & $2,501.8$ & $2,211.8$ & $1,159.4$ & $17.6 \%$ & 34.0 & 6.0 & 58.4 & 17.5 & 24.1 \\
\hline Guangxi & $4,668.4$ & $3,440.5$ & $2,382.5$ & $7.7 \%$ & 26.5 & 6.9 & 66.4 & 11.8 & 21.8 \\
\hline Guizhou & $3,604.1$ & $1,748.2$ & $1,857.1$ & $4.6 \%$ & 22.2 & 3.9 & 73.7 & 10.0 & 16.3 \\
\hline Hainan & 742.5 & $4,904.6$ & 335.3 & $11.3 \%$ & 9.6 & 3.9 & 60.7 & 11.7 & 27.6 \\
\hline Hebei & $6,621.6$ & $4,303.4$ & $3,367.3$ & $25.3 \%$ & 179.2 & 4.8 & 51.4 & 26.1 & 22.5 \\
\hline Inner Mongolia & $2,349.1$ & $3,545.5$ & $1,024.5$ & $21.9 \%$ & 59.0 & 3.8 & 52.4 & 22.0 & 25.6 \\
\hline Ningxia & 524.9 & $3,233.9$ & 243.6 & $5.9 \%$ & 0.6 & 23.8 & 58.9 & 19.1 & 22.0 \\
\hline Qinghai & 494.0 & $3,346.4$ & 226.0 & $4.1 \%$ & 1.4 & 6.6 & 59.9 & 18.2 & 21.9 \\
\hline Tibet & 246.5 & $2,271.0$ & \begin{tabular}{|c|}
113.7 \\
\end{tabular} & $0.0 \%$ & 0.0 & 0.0 & 77.2 & 4.6 & 18.2 \\
\hline Xinjiang & $1,705.7$ & $4,892.8$ & 662.2 & $7.6 \%$ & 14.3 & 3.5 & 56.9 & 18.8 & 24.3 \\
\hline Yunnan & $4,095.0$ & $2,946.7$ & $2,186.3$ & $12.5 \%$ & 85.0 & 3.2 & 75.8 & \begin{tabular}{l|}
9.9 \\
\end{tabular} & 14.3 \\
\hline Average & $2,504.9$ & $3,363.8$ & $1,232.5$ & $10.8 \%$ & \begin{tabular}{|l|}
39.3 \\
\end{tabular} & 4.5 & 62.9 & 15.4 & 21.7 \\
\hline
\end{tabular}


Table 2: Sources and Uses of Funds in Rural Credit Cooperatives

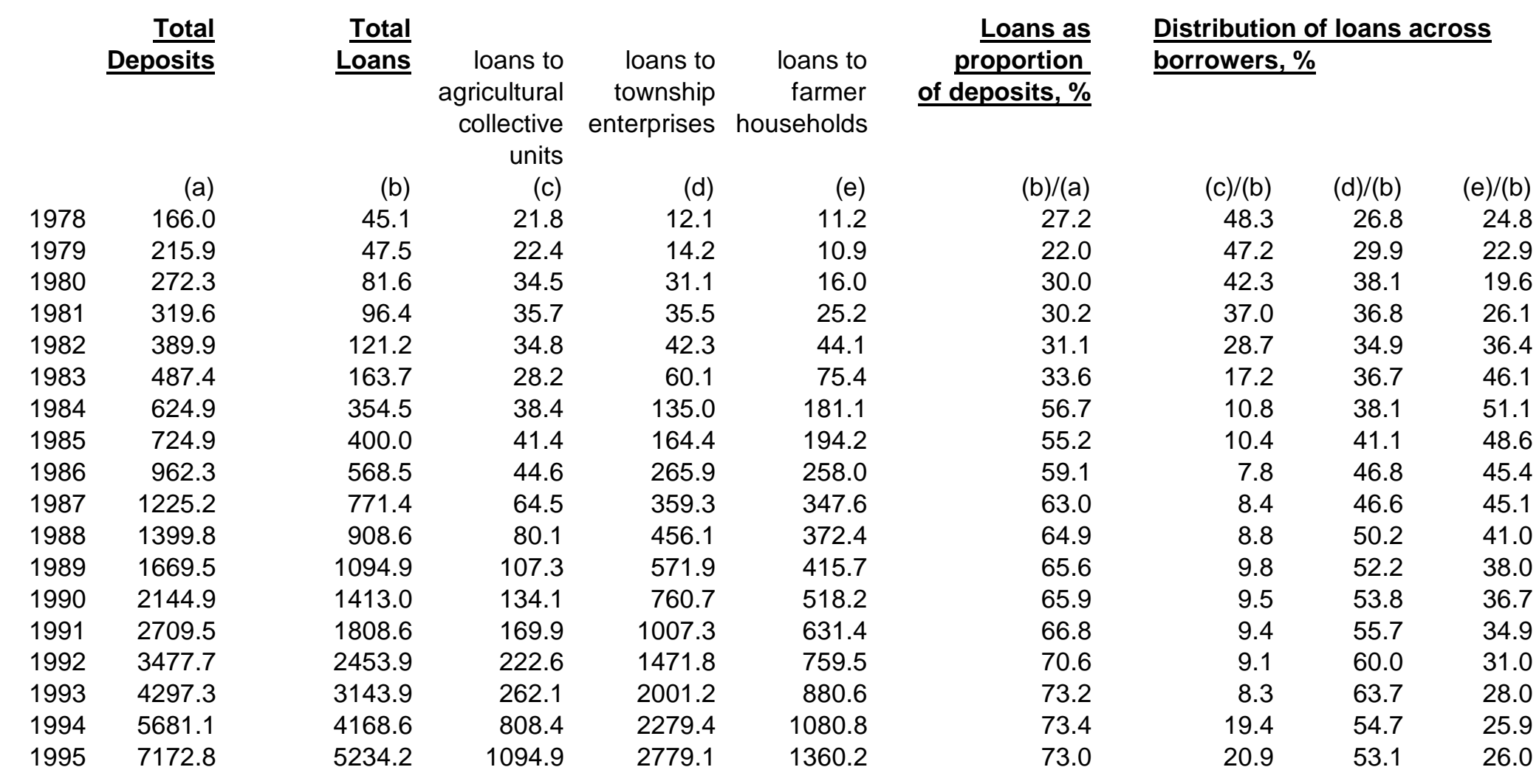

Constructed from the 1993 and 1995 issues of China Statistical Yearbook 
Table 3: Investment and Its Financing According to Ownership Forms

\begin{tabular}{|c|c|c|c|c|c|c|c|}
\hline & & & & Solely Hong & Foreign & & $\begin{array}{l}\text { Memo item: } \\
\text { Rural sector }\end{array}$ \\
\hline $\begin{array}{r}\text { National } \\
\text { total }\end{array}$ & $\begin{array}{r}\text { State-owned } \\
\text { enterprises }\end{array}$ & $\begin{array}{r}\text { Rural } \\
\text { collectives }\end{array}$ & $\begin{array}{r}\text { Rural } \\
\text { individuals }\end{array}$ & $\begin{array}{r}\text { Kong, Taiwan } \\
\text { and Macao }\end{array}$ & $\begin{array}{r}\text {-Financed } \\
\text { Firms }\end{array}$ & $\begin{array}{l}\text { Other } \\
\text { forms }\end{array}$ & $\begin{array}{r}\text { (collectives } \\
\& \text { individuals) }\end{array}$ \\
\hline
\end{tabular}

\begin{tabular}{|c|c|c|c|c|c|c|c|c|}
\hline 1985 & 28.93 & 19.11 & 2.27 & 5.44 & 0.00 & 0.00 & 2.10 & 7.71 \\
\hline 1996 & 34.19 & 17.65 & 4.09 & 3.71 & 1.38 & 2.91 & 4.44 & 7.81 \\
\hline Avg85-96 & 30.46 & 18.64 & 3.20 & 4.63 & 0.31 & 0.89 & 2.79 & 7.83 \\
\hline Avg85-88 & 29.97 & 19.15 & 2.72 & 5.72 & 0.00 & 0.00 & 2.37 & 8.45 \\
\hline Avg89-91 & 25.10 & 16.13 & 2.22 & 5.03 & 0.00 & 0.00 & 1.72 & 7.25 \\
\hline Avg92-96 & 34.07 & 19.74 & 4.17 & 3.50 & 0.75 & 2.14 & 3.77 & 7.68 \\
\hline
\end{tabular}

Part B: Share of Total Investment According to Ownership Form, in percent (each row, excluding memo item, sums to 100 )

$\begin{array}{lrrrrrrr}1985 & 66.08 & 7.83 & 18.81 & 0.00 & 0.00 & 7.28 & 26.65 \\ 1996 & 51.64 & 11.97 & 10.86 & 4.04 & 8.52 & 12.97 & 22.83 \\ & & & & & & & \\ \text { Avg85-96 } & 61.58 & 10.34 & 15.70 & 0.91 & 2.55 & 8.92 & 26.03 \\ \text { Avg85-88 } & 63.93 & 9.07 & 19.10 & 0.00 & 0.00 & 7.90 & 28.17 \\ \text { Avg89-91 } & 64.25 & 8.83 & 20.06 & 0.00 & 0.00 & 6.87 & 28.89 \\ \text { Avg92-96 } & 58.11 & 12.26 & 10.35 & 2.17 & 6.12 & 10.98 & 22.61\end{array}$

Part C: Funding for Investment by Each Type of Enterprise According to Source, in percent (for each year, elements within each column sum to 100)

$\underline{1985}$

a) State Budget

b)Domestic Loans

c)Foreign Investment

d)Self-raised funds

e)Others

$\underline{1996}$

a) State Budget

b)Domestic Loans

c)Foreign Investment

d)Self-raised funds

e)Others

$\begin{array}{rr}17.65 & 26.42 \\ 20.06 & 23.04 \\ 1.98 & 2.83 \\ 53.62 & 40.43\end{array}$

0.00

32.12

0.00

51.49

16.39

0.00

0.00

0.00

100.00

0.00

6.68

2.69

19.54

11.73

53.22

12.82

Average 1985-96

a)State Budget

b)Domestic Loans

c)Foreign Investment

d)Self-raised funds

e)Others

8.00
21.53
6.77
51.78
11.92


13.84
21.18
3.98
51.30
9.70

12.41

24.62

7.28

44.16

11.53

1.77

19.68

9.67

58.49

10.39

Average 1985-88

a)State Budget

b)Domestic Loans

c)Foreign Investment

21.33

0.00

7.15

23.63

34.06

0.00

6.02

0.00

3.53

39.39

44.71

0.00

e)Others

9.63

21.22

6.23
0.14

15.21

50.42

17.33

16.90
2.59

31.96

1.58

55.85

8.01

0.30

14.92

53.08

21.32

10.37

0.53

20.18

4.25

56.55

18.49

0.33
17.30

46.43

25.09

10.85

0.90

24.11

3.48

62.93

8.58

18.49

14.69
0.00

9.44

0.00

85.74

4.82

0.93

12.54

5.07

75.07

6.39

Average 1989-91

a)State Budget

b)Domestic Loans

7.91

12.26

0.00

0.00

4.39

0.75

1.48

29.44

2.14

61.70

5.23

0.29

14.30

1.56

69.85

14.01

20.11

24.18

25.26

20.92

0.00

13.35

0.00

75.52

11.13

0.00

10.78 


\begin{tabular}{|c|c|c|c|c|c|c|c|c|}
\hline c)Foreign Investment & 6.21 & 9.20 & 0.00 & 0.00 & & & 4.45 & 0.00 \\
\hline d)Self-raised funds & 53.85 & 42.69 & 47.36 & 86.79 & & & 69.26 & 74.75 \\
\hline e)Others & 11.92 & 11.67 & 27.38 & 8.82 & & & 4.62 & 14.47 \\
\hline \multicolumn{9}{|l|}{ Average 1992-96 } \\
\hline a)State Budget & 3.38 & 5.35 & 1.27 & 0.00 & 0.17 & 0.33 & 0.52 & 0.69 \\
\hline b)Domestic Loans & 22.65 & 25.67 & 27.71 & 4.58 & 14.96 & 17.30 & 21.77 & 17.16 \\
\hline c)Foreign Investment & 9.34 & 7.14 & 6.76 & 0.00 & 51.69 & 46.43 & 3.97 & 3.74 \\
\hline d)Self-raised funds & 50.92 & 48.86 & 40.81 & 88.54 & 18.49 & 25.09 & 60.11 & 62.37 \\
\hline e)Others & 13.71 & 12.97 & 23.44 & 6.89 & 14.69 & 10.85 & 13.63 & 16.04 \\
\hline
\end{tabular}

Part D: Destination of Funds from Each Source, percent going to each ownership type.

(each row, excluding Memo item, sums to 100)

1985

a)State Budget

b)Domestic Loans

c)Foreign Investment

d)Self-raised funds

e)Others

$\begin{array}{rrr}98.93 & 0.00 & 0.00 \\ 75.87 & 12.54 & 0.00 \\ 94.21 & 0.00 & 0.00 \\ 49.82 & 7.52 & 35.08 \\ 72.07 & 19.21 & 0.00\end{array}$

0.00

00

0.00

.08

1996

a)State Budget

b)Domestic Loans

c)Foreign Investment

d)Self-raised funds

e)Others

$88.44 \quad 7.86$

$62.30 \quad 12.05$

$29.52 \quad 9.86$

49.28

13.15

57.68

9.70

0.00

2.60

0.00

19.05

1.68

0.00

0.00

0.00

0.00

0.00

0.00

1.07

11.59

$0.00 \quad 5.79$

0.00

7.58

12.54

0.00

$0.00 \quad 8.72$

19.21

Average 1985-96

a)State Budget

b)Domestic Loans

c)Foreign Investment

d)Self-raised funds

e)Others

$\begin{array}{lll}96.35 & 2.10 & 0 .\end{array}$

$\begin{array}{lrr}70.57 & 13.87 & 2.99\end{array}$

$\begin{array}{lll}76.28 & 3.41 & 0.00\end{array}$

$\begin{array}{lll}52.38 & 8.56 & 26.72\end{array}$

59.86

20.54

9.44

0.21

0.94

6.50

2.54

13.40

17.38

38.53

4.70

13.78

18.72

3.41

5.33

6.89

9.86

32.20

11.38

Average 1985-88

a)State Budget

b)Domestic Loans

c)Foreign Investment

d)Self-raised funds

e)Others

$\begin{array}{rrr}99.14 & 0.00 & 0.00 \\ 71.41 & 14.57 & 3.06 \\ 95.49 & 0.00 & 0.00 \\ 49.16 & 7.79 & 33.50 \\ 64.22 & 20.27 & 10.87\end{array}$

0.00

3.06

0.00

33.50

10.87

$\begin{array}{lr}0.03 & 0.28 \\ 0.67 & 2.04 \\ 3.99 & 11.61 \\ 0.34 & 1.25 \\ 1.13 & 1.93\end{array}$

1.24

2.10

$\begin{array}{ll}9.86 & 16.87\end{array}$

$4.71 \quad 3.41$

$10.75 \quad 35.28$

$7.09 \quad 29.98$

Average 1989-91

a)State Budget

b)Domestic Loans

c)Foreign Investment

d)Self-raised funds

e)Others

$\begin{array}{rrr}99.35 & 0.00 & 0.00 \\ 77.25 & 11.19 & 4.39 \\ 95.06 & 0.00 & 0.00 \\ 51.07 & 7.76 & 32.35 \\ 63.10 & 20.43 & 13.71\end{array}$

0.00

0.00

0.00

0.86

0.00

$\begin{array}{llll}0.00 & 0.00 & 10.96 & 17.63\end{array}$

$\begin{array}{llll}0.00 & 0.00 & 4.51 & 0.00\end{array}$

$\begin{array}{llll}0.00 & 0.00 & 9.54 & 41.30\end{array}$

$\begin{array}{llll}0.00 & 0.00 & 4.64 & 31.14\end{array}$

Average 1992-96

a)State Budget

b)Domestic Loans

c)Foreign Investment

d)Self-raised funds

e)Others

$\begin{array}{rrrrrrr}92.32 & 5.04 & 0.00 & 0.08 & 0.66 & 1.90 & 5.04 \\ 65.88 & 14.93 & 2.11 & 1.60 & 4.89 & 10.59 & 17.04 \\ 49.63 & 8.18 & 0.00 & 9.57 & 27.88 & 4.74 & 8.18 \\ 55.75 & 9.66 & 17.91 & 0.82 & 2.99 & 12.87 & 27.57 \\ 54.44 & 20.82 & 5.74 & 2.71 & 4.64 & 11.65 & 26.56\end{array}$

The national total in Part A is constructed by summing up investment funding data from different funding sources. On the average, the former is smaller by 4 percent. The national total here is smaller than the fixed asset investment data from the revised national accounts reported in China Statistical Yearbook 1996, p.47 


\section{TABLE 4: INVESTMENT FINANCING OF COLLECTIVELY-OWNED TVES IN THE COASTAL AND CENTRAL PROVINCES}

\begin{tabular}{|c|c|c|c|c|c|c|c|}
\hline $\begin{array}{l}\text { 1. State } \\
\text { budget }\end{array}$ & $\begin{array}{l}\text { 2. Funds from } \\
\text { supervising } \\
\text { agency }\end{array}$ & $\begin{array}{r}\text { 3. Bank and } \\
\text { credit union } \\
\text { loans }\end{array}$ & $\begin{array}{l}\text { 4. Foreign } \\
\text { funds }\end{array}$ & $\begin{array}{l}\text { 5. Other funds } \\
\text { raised outside } \\
\text { of the firm }\end{array}$ & $\begin{array}{l}\text { 6. Bonds sold } \\
\text { to employees }\end{array}$ & $\begin{array}{r}\text { 7. Other } \\
\text { internal } \\
\text { funds }\end{array}$ & $\begin{array}{l}\text { 8. Other } \\
\text { Sources }\end{array}$ \\
\hline
\end{tabular}

Part A: TVE Investment Funding: Regional Share of National Total of Funds from Each Source (in percent)

(for each year within each column, the sum would be 100 for all 5 geographical groupings, or for all 30 provinces)

\begin{tabular}{|c|c|c|c|c|c|c|c|c|c|}
\hline \multicolumn{10}{|c|}{$\underline{\text { Coastal Provinces }}$} \\
\hline 1987 & $39.0 \%$ & $37.9 \%$ & $50.6 \%$ & $73.9 \%$ & $56.9 \%$ & $55.6 \%$ & $59.3 \%$ & $58.7 \%$ & $52.7 \%$ \\
\hline 1996 & $27.4 \%$ & $35.9 \%$ & $46.0 \%$ & $58.7 \%$ & $22.2 \%$ & $40.8 \%$ & $53.6 \%$ & $49.9 \%$ & $47.2 \%$ \\
\hline avg 89-91 & $42.4 \%$ & $43.6 \%$ & $51.3 \%$ & $65.8 \%$ & $44.5 \%$ & $59.3 \%$ & $61.4 \%$ & $63.5 \%$ & $53.8 \%$ \\
\hline avg 92-96 & $36.9 \%$ & $42.3 \%$ & $51.5 \%$ & $68.4 \%$ & $37.5 \%$ & $45.9 \%$ & $57.8 \%$ & $58.5 \%$ & $53.4 \%$ \\
\hline \multicolumn{10}{|c|}{ Central Provinces } \\
\hline 1987 & $27.2 \%$ & $20.9 \%$ & $24.7 \%$ & $17.5 \%$ & $22.3 \%$ & $30.0 \%$ & $18.8 \%$ & $24.5 \%$ & $23.3 \%$ \\
\hline 1996 & $45.5 \%$ & $27.3 \%$ & $28.9 \%$ & $12.6 \%$ & $44.9 \%$ & $34.4 \%$ & $24.4 \%$ & $29.8 \%$ & $27.7 \%$ \\
\hline avg 89-91 & $26.4 \%$ & $19.3 \%$ & $19.4 \%$ & $3.6 \%$ & $20.5 \%$ & $27.3 \%$ & $16.8 \%$ & $15.3 \%$ & $18.0 \%$ \\
\hline avg 92-96 & $32.2 \%$ & $23.8 \%$ & $24.1 \%$ & $10.9 \%$ & $32.4 \%$ & $30.9 \%$ & $20.9 \%$ & $23.5 \%$ & $23.1 \%$ \\
\hline \multicolumn{10}{|c|}{ Shandong (a coastal province) } \\
\hline 1987 & $11.5 \%$ & $10.5 \%$ & $12.6 \%$ & $10.0 \%$ & $5.2 \%$ & $14.6 \%$ & $14.7 \%$ & $14.7 \%$ & $12.7 \%$ \\
\hline 1996 & $8.9 \%$ & $8.5 \%$ & $17.1 \%$ & $6.6 \%$ & $7.4 \%$ & $11.6 \%$ & $16.1 \%$ & $13.8 \%$ & $13.7 \%$ \\
\hline avg 89-91 & $7.6 \%$ & $11.0 \%$ & $14.1 \%$ & $8.7 \%$ & $4.7 \%$ & $17.8 \%$ & $14.4 \%$ & $18.0 \%$ & $13.0 \%$ \\
\hline avg 92-96 & $7.0 \%$ & $11.9 \%$ & $15.8 \%$ & $9.8 \%$ & $9.7 \%$ & $12.9 \%$ & $17.0 \%$ & $16.5 \%$ & $14.7 \%$ \\
\hline \multicolumn{10}{|c|}{ Sichuan (a central province) } \\
\hline 1987 & $5.1 \%$ & $3.1 \%$ & $6.3 \%$ & $1.7 \%$ & $5.9 \%$ & $10.5 \%$ & $3.7 \%$ & $11.0 \%$ & $5.9 \%$ \\
\hline 1996 & $4.6 \%$ & $1.7 \%$ & $4.1 \%$ & $0.5 \%$ & $4.7 \%$ & $3.0 \%$ & $4.4 \%$ & $5.3 \%$ & $3.9 \%$ \\
\hline avg 89-91 & $4.2 \%$ & $3.3 \%$ & $3.3 \%$ & $0.1 \%$ & $5.4 \%$ & $7.0 \%$ & $3.5 \%$ & $4.6 \%$ & $3.7 \%$ \\
\hline avg 92-96 & $4.4 \%$ & $2.3 \%$ & $4.4 \%$ & $1.2 \%$ & $6.1 \%$ & $4.0 \%$ & $5.1 \%$ & $5.7 \%$ & $4.5 \%$ \\
\hline
\end{tabular}

Part B: TVE Investment: Composition of Funding from Each Source (in percent) (each row sums to 100 )

\begin{tabular}{|c|c|c|c|c|c|c|c|c|}
\hline \multicolumn{9}{|c|}{ National Average } \\
\hline 1987 & $3.6 \%$ & $7.1 \%$ & $48.4 \%$ & $1.2 \%$ & $5.6 \%$ & $4.7 \%$ & $21.8 \%$ & $7.7 \%$ \\
\hline 1996 & $0.6 \%$ & $1.8 \%$ & $24.6 \%$ & $10.3 \%$ & $10.8 \%$ & $6.6 \%$ & $36.4 \%$ & $8.9 \%$ \\
\hline avg 89-91 & $3.3 \%$ & $6.7 \%$ & $37.5 \%$ & $5.7 \%$ & $8.5 \%$ & $3.7 \%$ & $25.9 \%$ & $8.8 \%$ \\
\hline avg 92-96 & $1.0 \%$ & $3.0 \%$ & $29.6 \%$ & $8.8 \%$ & $9.0 \%$ & $7.4 \%$ & $31.9 \%$ & $9.4 \%$ \\
\hline \multicolumn{9}{|c|}{ Coastal Provinces } \\
\hline 1987 & $3.5 \%$ & $5.8 \%$ & $46.3 \%$ & $1.7 \%$ & $6.7 \%$ & $5.4 \%$ & $23.1 \%$ & $7.6 \%$ \\
\hline 1996 & $0.3 \%$ & $1.4 \%$ & $23.9 \%$ & $12.8 \%$ & $5.1 \%$ & $5.7 \%$ & $41.4 \%$ & $9.4 \%$ \\
\hline avg 89-91 & $2.8 \%$ & $5.7 \%$ & $33.5 \%$ & $8.2 \%$ & $6.2 \%$ & $4.4 \%$ & $29.1 \%$ & $9.9 \%$ \\
\hline avg 92-96 & $0.8 \%$ & $2.4 \%$ & $27.2 \%$ & $13.4 \%$ & $6.2 \%$ & $8.2 \%$ & $32.1 \%$ & $9.6 \%$ \\
\hline \multicolumn{9}{|c|}{ Central Provinces } \\
\hline 1987 & $4.9 \%$ & $7.4 \%$ & $51.5 \%$ & $0.9 \%$ & $5.1 \%$ & $5.1 \%$ & $18.8 \%$ & $6.2 \%$ \\
\hline 1996 & $0.9 \%$ & $1.8 \%$ & $25.6 \%$ & $4.7 \%$ & $17.4 \%$ & $8.2 \%$ & $32.0 \%$ & $9.6 \%$ \\
\hline $\operatorname{avg} 89-91$ & $5.3 \%$ & $7.7 \%$ & $41.3 \%$ & $0.9 \%$ & $8.3 \%$ & $5.3 \%$ & $23.8 \%$ & $7.4 \%$ \\
\hline avg 92-96 & $1.4 \%$ & $3.2 \%$ & $31.3 \%$ & $4.9 \%$ & $12.2 \%$ & $10.1 \%$ & $27.9 \%$ & $9.2 \%$ \\
\hline \multicolumn{9}{|c|}{ Shandong (a coastal province) } \\
\hline 1987 & $3.2 \%$ & $5.9 \%$ & $48.1 \%$ & $1.0 \%$ & $2.3 \%$ & $5.4 \%$ & $25.2 \%$ & $8.9 \%$ \\
\hline 1996 & $0.4 \%$ & $1.1 \%$ & $30.7 \%$ & $5.0 \%$ & $5.8 \%$ & $5.6 \%$ & $42.8 \%$ & $9.0 \%$ \\
\hline avg 89-91 & $1.9 \%$ & $5.6 \%$ & $40.7 \%$ & $3.1 \%$ & $3.0 \%$ & $5.1 \%$ & $28.6 \%$ & $12.1 \%$ \\
\hline avg 92-95 & $0.5 \%$ & $2.6 \%$ & $31.6 \%$ & $5.7 \%$ & $5.8 \%$ & $6.5 \%$ & $36.9 \%$ & $10.6 \%$ \\
\hline \multicolumn{9}{|c|}{ Sichuan (a central province) } \\
\hline 1987 & $3.1 \%$ & $3.7 \%$ & $51.4 \%$ & $0.3 \%$ & $5.5 \%$ & $8.4 \%$ & $13.4 \%$ & $14.3 \%$ \\
\hline 1996 & $0.7 \%$ & $0.8 \%$ & $25.6 \%$ & $1.3 \%$ & $13.0 \%$ & $5.1 \%$ & $41.4 \%$ & $12.1 \%$ \\
\hline avg 89-91 & $3.8 \%$ & $6.2 \%$ & $33.4 \%$ & $0.1 \%$ & $13.0 \%$ & $7.3 \%$ & $25.3 \%$ & $11.0 \%$ \\
\hline avg 92-96 & $1.0 \%$ & $1.5 \%$ & $28.7 \%$ & $2.2 \%$ & $12.1 \%$ & $6.4 \%$ & $36.1 \%$ & $12.0 \%$ \\
\hline
\end{tabular}

Data from various issues of TVE yearbooks. 1988 data are not available. 